\title{
Irrigation and Leaf Removal Effects on Polyphenolic Content of Grapes and Wines Produced from cv. 'Agiorgitiko' (Vitis vinifera L.)
}

\author{
Evangelia $\mathrm{CHORTI}^{1}$, Maria KYRALEOU ${ }^{2}$, Stamatina KALLITHRAKA ${ }^{2}$, Manolis \\ PAVLIDIS ${ }^{2}$, Stefanos KOUNDOURAS ${ }^{3}$, Ioannis KANAKIS ${ }^{4}$, Yorgos KOTSERIDIS ${ }^{2 *}$ \\ ${ }^{1}$ CooperativeWineryof Nemea, 130Papaconstantinouav.,20500Nemea,Greece; echorti@nemeanwines.gr \\ 2Agricultural University of Athens, DepartmentofFoodScience w Technology,75IeraOdos, 11855 Athens, Greece; mkyraleou@yahoo.gr; stamatina@aua.gr; \\ mavlidis@hotmail.com;ykotseridis@aua.gr(*orrespondingauthor) \\ ${ }^{3}$ AristotleUniversity of Thessaloniki, Schoolof Agriculture,Laboratory of Viticulture, 54124, Thessaloniki,Greece; skoundou@agro.auth.gr \\ ${ }^{4}$ Fassoulis GrapevineNurseries,20500Leontio-Nemea, Greece; kanakis@fassoulis.gr
}

\begin{abstract}
Vitis vinifera L. cv. 'Agiorgitiko' is one of the most important red grape varieties of Greece, cultivated almost exclusively in the region of Nemea in north-eastern Peloponnese. This work aimed to study the influence of some commonly applied viticultural practices on the polyphenolic composition of 'Agiorgitiko'. Leaf removal at veraison, irrigation, and a combination of both, were applied and the phenolic content of the grapes and of the produced wines was compared. The results showed that leaf removal decreased berry size, enhanced total anthocyanin, total phenol and malvidin 3-O-monoglucoside accumulation in skins and increased the amount of extractable anthocyanins in the juice. The combination of irrigation and leaf removal caused a significant increase in total phenols in the skin and in the amount of extractable anthocyanins in juice. As far as the produced wines were concerned, color intensity, tannin content and total polyphenols were increased due to leaf removal. Both irrigation and leaf removal resulted in wines with the highest concentration of malvidin 3-O-monoglucoside, although neither practice resulted in any significant difference in anthocyanin concentration of the wines. Vines where only irrigation was applied produced berries with reduced extractable anthocyanins, increased seed total phenols and lower wine total tannins. The study showed that increasing cluster sun exposure of 'Agiorgitiko' vines may be, overall, beneficial to the quality of the produced wine.
\end{abstract}

Keywords: anthocyanins, defoliation, irrigation, phenolic compounds, tannins

\section{Introduction}

Several strategies have been applied in order to increase the content of phenolic compounds in wine during the process of grape growing and wine making. Most of the viticultural practices applied in the vineyard are focusing on increasing light penetration and air circulation into the canopy because of the benefits that they present: reduced humidity (Haselgrove et al., 2000), reduced risk of fungal and bacterial infection (Emmett $e t$ al, , 1992), increased berry temperature and possibly increased vine development, metabolite accumulation and wine quality (Bordelon et al., 2008).

However, fruit zone defoliation effects on grape composition are not always consistent, depending on timing, severity of application, and grapevine genotype. Defoliation, either pre-bloom or postbloom, has been adopted as an effective means for both yield control and wine quality improvement. The positive effect of pre-bloom leaf removal on grape composition has been often attributed to lower cluster and berry size at harvest. Moreover, cell division in the berry skin seems to be sensitive to temperature, hence, exposed grapes have thicker berry skin and increased skin-to-pulp ratio (Palliotti $e t$ al., 2011). At the whole vine level, pre-bloom defoliation was reported to increase leaf area-to-fruit ratio due to reduced fruit set and/or berry size and to leaf area recovery after veraison (Intrieri et al., 2008). In contrast, fruit zone defoliation at berry set was found to reduce whole vine photosynthesis at an early stage (Petrie et al., 2003). Moreover, post-bloom defoliation was reported to be ineffective in lowering cluster weight and berry number per cluster in 'Graciano' and 'Carignan', whereas final total leaf area per shoot was reduced, with no evident compensation for lateral leaf area (Tardaguila et al., 2010).

In cool climates, increased sunlight exposure is related to enhanced anthocyanin and phenolic production (Ristic et al., 2007). However, it is under consideration whether this practice can be beneficial to wine quality in warm to hot and sunny climates, since extended cluster exposure could sharply increase berry temperature 
134

and thus reduce the anthocyanin content of the grapes (Lorrain et al, 2011). Moreover, excessive sunlight exposure has been known to occasionally cause sunburn cluster damage without increasing total soluble solids or anthocyanin accumulation (Chorti et al, 2010). The results reported by Petropoulos et al. (2011) regarding 'Agiorgitiko' wines suggested that the extreme hot and dry conditions may have a greater effect on grape phenolic content than any other viticultural practice, and therefore, viticultural practices increasing light exposure of grape bunches may not be beneficial for the wine quality.

In general, the results regarding leaf removal are variable since they may be influenced by many parameters such as training system, fruit load, vine age, fertility, cultivar, rootstock, irrigation practice and macroclimate (Main and Morris, 2004).

Irrigation management seems to be another important factor, and the most controllable one as it is, determining grape and wine quality (Fereres and Evans, 2006), especially in arid and semi-arid areas, with the primary focus on grape phenolic compounds (Kennedy et al., 2002; Ojeda et al., 2002). Koundouras et al. (2009) found that water limitation, especially pre-veraison, notably increased anthocyanin concentration in skin, affecting biosynthesis directly, with the greater effect on malvidin 3-O-monoglucoside (Mlv).

However, studies have often shown contradictory effects of water on berry components, mainly because of different irrigation volumes, period of water application and environmental conditions, leading to variations in water availability (Koundouras et al, 2009). Studies have shown that severe water deficit that usually occurs under semiarid conditions could be detrimental to fruit quality because of inadequate leaf area to ripen fruit or excessive grape exposure to sunlight leading to lower pigmentation in grapes as a result of increased berry temperature (Price et al., 1995).

'Agiorgitiko' is one of the most important indigenous red grape varieties cultivated in Greece. In its region of origin, Nemea, 'Agiorgitiko' gives Denomination of Origin, deeply colored red wines (Koundouras et al, 2006). The wine region of Nemea, where 'Agiorgitiko' is almost exclusively grown, has a Mediterranean type climate, characterized by high temperatures and water deficiency during the summer season. There is lack of information concerning the relationship between irrigation and leaf removal and wine quality due to the uniqueness of this grape variety and its limited cultivation area. In this study, the above practices were applied in the vineyard and the quality of the produced wines was determined based on two quality parameters of red wines, anthocyanin content and tannin composition.

\section{Materials and Methods}

\section{Experimental conditions}

The experiment was conducted in 2010 in a 12-year old commercial vineyard in Leontio sub-region of Nemea (northeastern Peloponnese, Greece), at an altitude of $300 \mathrm{~m}$ above sea level. The soil in the location of the vineyard is clay and deep with good nutrient availability and water-retention capacity.

The vineyard was planted with Vitis vinifera L. cv. 'Agiorgitiko' grafted onto 1103P rootstock. Vine spacing was $1 \mathrm{~m}$ and row spacing was $2.5 \mathrm{~m}$ and the vines were trained to a bilateral cordon Royat consisting of four spurs per cordon, pruned to two buds per spur.

Four different treatments were applied: control (C), irrigation (I), leaf removal (LR), combination of irrigation and leaf removal (I/LR). Leaf removal consisted in removing all leaves around the clusters at veraison, on both sides of the row, in order to obtain maximum sunlight exposure. Irrigation was applied by a drip irrigation system (one emitter every $33 \mathrm{~cm}$ ) based on crop evapotranspiration with one application of $200 \mathrm{~mm}$ ha-1 on 4/8/2010. Apart from leaf removal, canopy management was similar for all treatments and included shoot tucking and positioning and shoot topping to about $1.2 \mathrm{~m}$ above the bottom wire.

All four treatments were replicated four times. Harvest was conducted simultaneously for the four treatments on 15/9/10. On the same day, 750 berries were sampled from each replicate of each treatment. The sampled berries from two replicates of each treatment at a time were united, thus providing two replicates for each of the four treatments, which were subsequently vinified separately.

\section{Phenolic content of grapes \\ Homogenized berries}

A number of 50 berries from each treatment were homogenized using Ultra Turrax T25 at 24,000 rpm for $1 \mathrm{~min}$. Total phenols and anthocyanin content were measured according to Iland et al. (2004); $1 \mathrm{~g}$ of the homogenate (in triplicate) was transferred into a centrifuge tube. An amount of $10 \mathrm{~mL} \mathrm{50 \%} \mathrm{v/v}$ aqueous ethanol, $\mathrm{pH} 2$, was then added and mixed for $1 \mathrm{~h}$. After centrifugation at $3,500 \mathrm{rpm}$ for $10 \mathrm{~min}, 0.5 \mathrm{~mL}$ of the supernatant was added to $10 \mathrm{~mL} 1 \mathrm{M} \mathrm{HCl}$ and mixed thoroughly. After $3 \mathrm{~h}$, absorbance at $520 \mathrm{~nm}$ and $280 \mathrm{~nm}$ was recorded.

Anthocyanin content, extractable anthocyanins and \% contribution of skin and seed to total berry tannins (skin\% and seed\% respectively) were determined as described by RibereauGayon et al. (1999), slightly modified. An amount of $20 \mathrm{~g}$ of the homogenate was macerated for $4 \mathrm{~h}$ with two different buffers. The $\mathrm{pH}$ of the first buffer was set at 1 while the $\mathrm{pH}$ of the second at 3.6. After $4 \mathrm{~h}$, the macerated samples were centrifuged (4,000 rpm, 10 $\mathrm{min}$ ) and then the anthocyanin and total phenolic content was measured on the supernatant.

\section{Seed andskin extracts}

Seeds and skins of 150 berries were removed by hand from grapes. Then they were freeze-dried and finally were grounded to obtain fine powder.

The extraction of skin and seed tannins was carried out according to previously reported methods (Lorrain et al., 2011). A $3 \mathrm{~g}$ portion of the obtained powder was firstly extracted with $25 \mathrm{~mL}$ mixture of acetone/water $(80: 20, \mathrm{v} / \mathrm{v})$ for $3 \mathrm{~h}$ and then with $25 \mathrm{~mL}$ mixture of methanol/water $(60: 40, \mathrm{v} / \mathrm{v})$ for $2.5 \mathrm{~h}$. The centrifugal supernatants were combined and evaporated under reduced pressure at $30^{\circ} \mathrm{C}$ to remove organic solvents; the residue was dissolved in water and lyophilised to obtain a crude tannin extract.

A part of the crude extracts was re-dissolved in a model solution (12\% ethanol; $5 \mathrm{gL}^{-1}$ tartaric acid; $\mathrm{pH} 3.5$ adjusted with $1 \mathrm{~N} \mathrm{NaOH}$ ) for the determination of Total Phenol Content by Folin Ciocalteu method (Waterman and Mole, 1994), antioxidant activity (Brand-Williams et al., 1994) and total tannin estimation through the protein precipitation assay using bovine serum albumin- BSA (Harbertson et al., 2003). Absorbance measurements were recorded on a Jasco V-530 UV/VIS spectrophotometer.

Anthocyanins were extracted with acidified methanol $(0.1 \%$ $\mathrm{HCl} 12 \mathrm{~N}$ ) from $1 \mathrm{~g}$ of dried skin powder at three successive 
times (for 4, 18 and $24 \mathrm{~h}$ ). After centrifugation, the supernatants were combined and analysed for total anthocyanins (RibereauGayon et al., 1999). HPLC analysis was carried out for the determination of monomeric anthocyanins on a Ristek pinnacle II C18, $250 \times 4.6,5 \mu \mathrm{m}$ at a flow rate of $1 \mathrm{~mL} \mathrm{~min}^{-1}$, using a 10 $\mu \mathrm{L}$ injection volume, detection at $520 \mathrm{~nm}$, and the following elution program: $90 \%$ eluent A for $1 \mathrm{~min}$, then from $90 \%$ to $50 \%$ in $22 \mathrm{~min}$, from $50 \%$ to $5 \%$ in $10 \mathrm{~min}$, which was kept isocratic for further $2 \mathrm{~min}$. Eluent A was 10\% aqueous formic acid and eluent B methanol. Identification and quantification was performed by establishing calibration curve for malvidin 3$\mathrm{O}$-monoglucoside (Mlv). Results were expressed as $\mu \mathrm{g} \mathrm{Mlv} \mathrm{per} \mathrm{g}$ dry skin weight. All analyses were performed in triplicate.

\section{Wines}

The grapes used for the production of the experimental wines were harvested at their optimum technological maturity as judged by indices of sugar content (remain constant for two consecutive days). Duplicate fermentations were performed for each treatment. After crushing and destemming, $60 \mathrm{mg} \mathrm{L}^{-1} \mathrm{SO}_{2}$ (as potassium metabisulfite) was added to the grapes. Lyophilized yeasts of the commercial strain F10 Laffort at $20 \mathrm{~g} \mathrm{hL}^{-1}$, previously hydrated in water $\left(15 \mathrm{~min}, 38^{\circ} \mathrm{C}\right)$ were also added. Beginning on the second day of fermentation, and for the following days, two punching downs per day were conducted.

After seven days of maceration at controlled temperature $\left(23-25^{\circ} \mathrm{C}\right)$, the wines were pressed and transferred to other tanks and spontaneous malolactic fermentation was completed after approximately three weeks. The wines were racked, coldstabilized, supplemented with $50 \mathrm{mg} \mathrm{L}^{-1} \mathrm{SO}_{2}$ (as potassium metabisulfite), filtered, bottled and stored at $15 \pm 2^{\circ} \mathrm{C}$ in the dark until analysed.

\section{Phenolic content of the wines}

In wines several classical analytical parameters ( $\%$ vol, hue, color intensity, total polyphenols - OD280) were determined after bottling according to the OIV methods (1990). In addition, their total phenolic content by Folin-Ciocalteau (Waterman and Mole, 1994), total anthocyanin content, ionization index, total tannins (Ribereau-Gayon et al., 1999; Harbertson et al., 2003), antioxidant activity (Brand-Williams et al., 1994) and monomeric anthocyanins by HPLC (Kallithraka et al., 2006) were also determined. All analyses were performed in triplicate.

\section{Statistical analysis}

Data were subjected to one-way analysis of variance (ANOVA) using Statistica Version 7 (StatSoft Inc., Tulsa, OK, USA) and comparison of mean values was performed by Tuckey's honest significant difference (HSD) test when samples were significantly different after ANOVA $(P \leq 0.05)$.

\section{Results and Discussion}

\section{Growth components}

Berries from LR were smaller (Fig. 1), although there was no difference among treatments in seed and skin weight which leads to conclude that they had lower pulp mass compared to the other treatments. According to Kotseridis et al. (2012) when leaf removal was applied before bloom, it had no effect on berry size in the case of 'Merlot' and 'Sangiovese' grapes, but reduced it in the

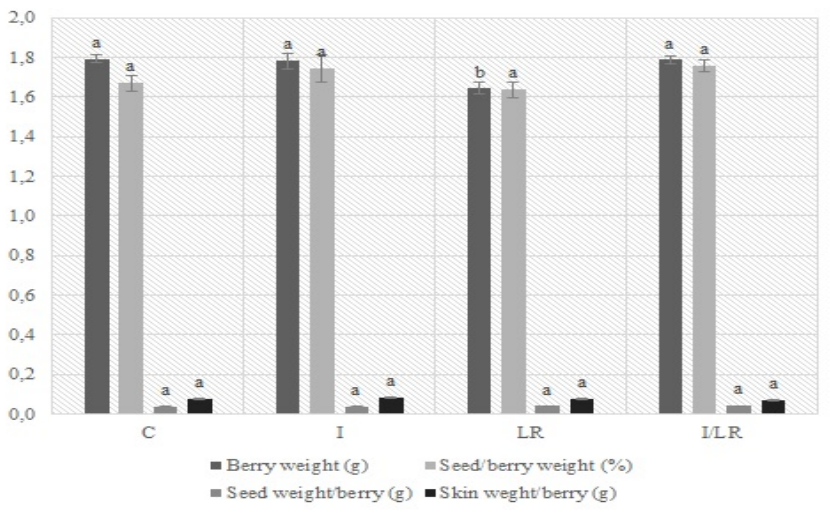

Fig. 1. Growth components measured at harvest. Different letters within a parameter denote significant differences (Tukey's test, $\mathrm{p} \leq 0.05$ ).

case of 'Cabernet Sauvignon' grapes, leading to conclude that the effect may be cultivar-related. Irrigation had no effect on berry size, in contrast with studies showing that irrigation increases berry weight at harvest (Koundouras et al., 2009). Moreover, Kyraleou et al. (2016a) observed a significant trend towards smaller berries in non-irrigated vines when compared with the full-irrigated ones. Similar results on the influence of water deficit on berry growth were reported previously for 'Shiraz' (Ojeda et al., 2001), 'Cabernet Sauvignon' (Robby and Matthews, 2004), 'Cabernet franc' (Matthews and Anderson, 1989) and 'Tempranillo' (Santesteban et al., 2011). This reduction was attributed to the decreased cell volume of the pericarp cells in water stressed berries leading to reduced skin cell wall extensibility and, therefore, to a reduced enlargement potential of berries (Kyraleou et al., 2016a). However, water effects on berry components are often contrasting, mainly because of different irrigation volumes and environmental conditions, leading to variations in water availability.

\section{Berry composition}

Previous studies have shown contradictory results on anthocyanin accumulation of berries exposed to high light incidence. Although it is generally believed that elevated light exposure enhances anthocyanin accumulation (Dokoozlian and Kliewer, 1996; Jeong et al., 2004), some papers reported a negative (Bergqvist et al., 2001; Haselgrove et al., 2000; Spayd et al., 2002), or no effect whatsoever (Chorti et al., 2010) in anthocyanin content. These differences observed could be attributed to different temperature conditions as well as cultivar specificity. It has been suggested that berry skin temperature has more influence on anthocyanin accumulation than light (Spayd et al.2002; Mori et al. 2005; Tarara et al. 2008) and that the effect of temperature can vary greatly along developmental stages (Yamane et al. 2006) Incident solar radiation increases berry temperature and during the day it can result $11^{\circ} \mathrm{C}$ greater or even more compared to berries naturally shaded by leaves, according to the time of day and weather conditions (Kliewer and Lider 1968; Reynolds et al 1986).

In the present study, both treatments where leaf removal was applied (LR and I/LR) showed an increase in anthocyanin and total phenol content both per berry and per g of berry (Table 1). However, high-colored grapes per se are not enough in order to obtain high-colored wines, which may be dependent on the ease with which anthocyanins are extracted from grape skins into must 
136

(Romero-Cascales et al., 2005). Anthocyanin extractability is a very important parameter affecting the color of the produced wine. The lower the anthocyanin extractability index (\%AE) is the higher the potential amount of anthocyanins extracted. As shown in Table 1, leaf removal (LR and I/LR) did not lead to different \%AE compared to control, although it seems that the application of irrigation only results in lower anthocyanin extractability (higher $\% \mathrm{AE}$ ).

The LR treatment showed the highest antocyanin content potential (total anthocyanins in $\mathrm{mg} \mathrm{L}^{-1}$ of juice and extractable anthocyanins in $\mathrm{mg} \mathrm{L}^{-1}$ of juice) as shown in Table 1 as well as the highest Mlv content. Kotseridis et al. (2012) also found that leaf removal induced Mlv accumulation in 'Merlot' and 'Cabernet Sauvignon', although it had limited effect in 'Sangiovese'. The increased anthocyanin and Mlv content in vines that underwent defoliation (LR and I/LR) should probably be attributed to an enhanced anthocyanin biosynthesis caused by leaf removal rather than a result of reduced berry size, since the amount of anthocyanins per $\mathrm{g}$ of skin was higher in LR (followed by I/LR) and there were no differences observed in skin weight among the treatments, as already mentioned. According to Matus et al. (2009), increased exposure to solar radiation enhanced the specific anthocyanin biosynthetic gene encoding UDP-glucose:flavonoid 3-O-glucosyltransferase in 'Cabernet Sauvignon'. Similar results were obtained by Pertopoulos, et al. (2011) who observed that the concentration of malvidin-3-O-glucoside and its esters of 'Agiorgitiko' wines were positively influenced by leaf removal.

Irrigation and leaf removal also enhanced the contribution of both seed and skin tannins (Table 1).

Many studies using artificial shading, defoliation and other techniques have shown alterations in the production of tannins and anthocyanins (Bavaresco et al., 2008; Tarara et al., 2008). In cool climates, increased light penetration is related to enhanced anthocyanin and phenolic production (Ristic et al., 2007). However it is under consideration whether this practice can be beneficial to wine quality in warm to hot and sunny climates (Dry et al., 2009), since extended bunch exposure could sharply increase bunch temperature and thus reduce the anthocyanin content of grapes (Lorrain et al., 2011).

\section{Seed and skin extracts}

The combination of leaf removal and irrigation caused a decrease in total tannin content of skins, but it had no similar effect on the seed tannin content (Table 2). No significant differences were observed among the other treatments. This result is in agreement with the results of a study conducted with 'Shiraz' grapes, where it was shown that at harvest, there were no significant differences between the tannin content of shaded and non-shaded grapes (Downey et al., 2003).

Regarding total phenolic content (TP), seeds on average contained higher amounts than skins (Table 2) in agreement with the findings of Kyraleou et al. (2016b). Moreover, irrigation (I) resulted in higher TP in seeds, while there were no differences among treatments in total phenolic content of the skins. According to Kyraleou et al. (2016b), irrigation had a significant effect on TP of both skin and seed samples. All irrigated samples contained significantly higher TP amounts compared to nonirrigated ones, indicating that irrigation may have a positive effect on total phenolic content of grapes.

Regarding total tannin content, seeds were richer than skins (Table 2), in agreement with the results presented previously (Kyraleou et al., 2016b). Moreover, Kyraleou et al. (2016b) reported that the fully-irrigated seed samples were significantly richer in total tannins than the non-irrigated ones (in the first year of their study) while during the second year, no significant differences were observed among the two different irrigation regimes. In skin samples, irrigation did not result in any significant differences in their total tannin content during the first year of the study, while during the second year of the experiment irrigated skin samples were richer that non-irrigated ones.

In previous studies, water deficit did not alter the concentration of seed tannins in 'Shiraz' (Roby et al., 2004) and 'Cabernet Sauvignon' (Koundouras et al., 2009), while in two recent studies, irrigation resulted either in decreased content of tannins in 'Cabernet Sauvignon' seeds (Casassa et al., 2015) or increased content of both seed and skin tannins in 'Shiraz' grapes (Bonada et al., 2015).

Finally, the different treatments seem to have no effect on the antioxidant activity of neither seeds nor skins (Table 2), consistent with the results reported by Kyraleou et al., (2016a) where no significant differences were detected concerning the antioxidant activity among the irrigated and non-irrigated samples, indicating that irrigation did not significantly affect this parameter.

\section{Wine composition}

As shown in Table 3, the vines of the LR treatment produced the wine with the highest color intensity, the highest ionization index and the lowest color hue, similar to the results reported by Gubler et al. (1992), Zoecklein et al. (1992) and Percival et al. (1994).

Although some differences were observed in total anthocyanin content of grapes, as shown above, this was not mirrored in the wine produced by those berries, since there were no differences in the anthocyanin content among treatments (Fig. 2). This could be

Table 1. Phenolic potential of berries

\begin{tabular}{|c|c|c|c|c|}
\hline Parameter & $\mathrm{C}$ & I & LR & I/LR \\
\hline Anthocyanins (mg/berry) & $1.553 \pm 0.0222 \mathrm{a}$ & $1.472 \pm 0.0379 \mathrm{a}$ & $1.714 \pm 0.051 \mathrm{~b}$ & $1.558 \pm 0.037 \mathrm{a}$ \\
\hline Anthocyanins (mg/berry g) & $0.799 \pm 0.0133 \mathrm{a}$ & $0.801 \pm 0.0184 \mathrm{a}$ & $0.973 \pm 0.0266 b$ & $0.834 \pm 0.019 a$ \\
\hline Total Phenols (au/berry) & $2.27 \pm 0.053 \mathrm{a}$ & $2.32 \pm 0.062 \mathrm{a}$ & $2.60 \pm 0.078 b$ & $2.43 \pm 0.048 \mathrm{ab}$ \\
\hline Total phenols (au/berry g) & $1.168 \pm 0.0326 \mathrm{a}$ & $1.265 \pm 0.027 \mathrm{ab}$ & $1.478 \pm 0.0338 c$ & $1.303 \pm 0.024 b$ \\
\hline Anthocyanin extractability (\%AE) & $27.012 \pm 0.892 \mathrm{ab}$ & $35.966 \pm 1.367 \mathrm{c}$ & $30.969 \pm 1.029 b$ & $24.84 \pm 0.760 a$ \\
\hline Total anthocyanins ( $\mathrm{mg} \mathrm{L}^{-1}$ juice) & $350.36 \pm 2.21 \mathrm{ab}$ & $342.94 \pm 14.24 \mathrm{a}$ & $448.36 \pm 3.97 c$ & $374.37 \pm 4.07 b$ \\
\hline Extractable anthocyanins ( $\mathrm{mg} \mathrm{L}^{-1}$ juice $)$ & $255.66 \pm 2.81 b$ & $219.00 \pm 8.01 \mathrm{a}$ & $309.44 \pm 4.77 \mathrm{~d}$ & $281.24 \pm 2.74 \mathrm{c}$ \\
\hline mg malvidin $\mathrm{g}^{-1} \mathrm{dw}$ skins & $9.65 \pm 0.21 \mathrm{c}$ & $8.43 \pm 0.16 \mathrm{~d}$ & $12.91 \pm 0.37 \mathrm{a}$ & $11.02 \pm 0.36 b$ \\
\hline $\begin{array}{l}\% \text { contribution of seed tannins } \\
\text { (seed\%) }\end{array}$ & $63.07 \pm 0.538 b$ & $73.61 \pm 0.779 \mathrm{a}$ & $75.89 \pm 0.668 \mathrm{a}$ & $75.58 \pm 0.581 \mathrm{a}$ \\
\hline $\begin{array}{l}\% \text { contribution of skin tannins } \\
(\text { skin } \%)\end{array}$ & $18.17 \pm 0.154 b$ & $26.38 \pm 0.779 a$ & $24.10 \pm 0.668 \mathrm{a}$ & $24.41 \pm 0.581 \mathrm{a}$ \\
\hline
\end{tabular}


Table 2. Seed and skin extracts components

\begin{tabular}{|c|c|c|c|c|}
\hline Parameter & $\mathrm{C}$ & I & $\overline{L R}$ & I/LR \\
\hline Total tannins ( $\mathrm{mg}$ catechin $\mathrm{g}^{-1} \mathrm{dw}$ seeds) & $34.78 \pm 1.35 a$ & $34.85 \pm 1.15 \mathrm{a}$ & $37.05 \pm 1.03 \mathrm{a}$ & $37.01 \pm 0.85 \mathrm{a}$ \\
\hline Total tannins ( $\mathrm{mg}$ catechin $\mathrm{g}^{-1} \mathrm{dw}$ skins) & $11.72 \pm 0.342 \mathrm{a}$ & $11.91 \pm 0.409 \mathrm{a}$ & $12.21 \pm 0.417 \mathrm{a}$ & $8.02 \pm 1.157 \mathrm{~b}$ \\
\hline Total Phenols (mg gallic acid $\mathrm{g}^{-1} \mathrm{dw}$ seeds) & $96.51 \pm 1.75 a$ & $105.84 \pm 1.33 \mathrm{~b}$ & $94.21 \pm 1.63 a$ & $97.19 \pm 1.13 a$ \\
\hline Total phenols (mg gallic acid $\mathrm{g}^{-1} \mathrm{dw}$ skins) & $54.87 \pm 1.116 \mathrm{a}$ & $56.34 \pm 1.912 \mathrm{a}$ & $55.34 \pm 1.616 \mathrm{a}$ & $51.71 \pm 0.908 \mathrm{a}$ \\
\hline Antioxidant activity (mMtrolox $\mathrm{g}^{-1} \mathrm{dw}$ seeds) & $0.175 \pm 0.002 \mathrm{a}$ & $0.179 \pm 0.002 \mathrm{a}$ & $0.181 \pm 0.003 \mathrm{a}$ & $0.183 \pm 0.001 \mathrm{a}$ \\
\hline Antioxidant activity (mMtrolox $\mathrm{g}^{-1} \mathrm{dw}$ skins) & $0.20 \pm 0.006 \mathrm{a}$ & $0.21 \pm 0.004 \mathrm{a}$ & $0.20 \pm 0.004 \mathrm{a}$ & $0.1758 \pm 0.026 \mathrm{a}$ \\
\hline
\end{tabular}

Note: Different letters within a row denote significant differences (Tukey's test, $\mathrm{p} \leq 0.05$ ). au, absorbance units; dw, dry weight.

Table 3. Wine color components

\begin{tabular}{ccccc}
\hline Parameter & $\mathrm{C}$ & $\mathrm{I}$ & $\mathrm{LR}$ & $\mathrm{I} / \mathrm{LR}$ \\
\hline $\begin{array}{c}\text { Ionization } \\
\text { index } \%\end{array}$ & $12.54 \pm 0.56 \mathrm{c}$ & $12.32 \pm 0.41 \mathrm{c}$ & $22.97 \pm 1.47 \mathrm{a}$ & $16.38 \pm 0.39 \mathrm{~b}$ \\
$\begin{array}{c}\text { Color } \\
\text { hue }\end{array}$ & $0.690 \pm 0.015 \mathrm{a}$ & $0.698 \pm 0.011 \mathrm{a}$ & $0.634 \mathrm{~b}$ & $0.67 \pm 0.01 \mathrm{ab}$ \\
$\begin{array}{c}\text { Color } \\
\text { Intensity }\end{array}$ & $4.71 \pm 0.08 \mathrm{c}$ & $4.74 \pm 0.02 \mathrm{c}$ & $7.73 \pm 0.34 \mathrm{a}$ & $5.83 \pm 0.12 \mathrm{~b}$ \\
\hline
\end{tabular}

Note: Different letters within a row denote significant differences (Tukey's test, $\mathrm{p} \leq 0.05)$.

a result of low extractability counterbalancing the higher anthocyanin content. The concentration of malvidin-3-glucoside is higher in I/LR treatment only in comparison to control.

Berries from LR treatment had the highest total polyphenols, followed by I/LR (Fig. 2). Those same two treatments were the ones with the highest total tannin content. Irrigation alone, on the other hand, led to the lowest total tannin content, in contrast with other study (Bonada et al., 2015) that suggests that water availability has no effect on the content and concentration of tannins, phenolic substances and skin- and seed- derived tannins. Leaf removal seems to have caused a decrease in total phenols (expressed as gallic acid equivalents).

\section{Conclusion}

Leaf removal and irrigation are two viticultural practices widely applied in order to achieve better quality in grapes and wine. The results of this study demonstrate that the leaf removal of Agiorgitiko vines resulted in smaller grapes with increased total anthocyanin, total phenolic and malvidin 3-Omonoglucoside contents and in wines with higher color intensity and total tannin concentration. Moreover, when irrigation was combined with leaf removal anthocyanin extractability was increased significantly. Vines where only irrigation was applied produced berries with reduced anthocyanin extractability, increased seed total phenols and decreased wine total tannins. Overall, increasing cluster sun exposure of 'Agiorgitiko' vines may be, beneficial to the quality parameters of the produced wine.

\section{References}

Bergqvist J, Dokoozlian N, Ebisuda N (2001). Sunlight exposure and temperature effects on berry growth and composition of Cabernet Sauvignon and Grenache in the Central San Joaquin Valley of California. American Journal of Enology and Viticulture 52:1-7.

Bonada M, Jeffery DW, Petrie PR, Moran MA, Sadras VO (2015). Impact of elevated temperature and water deficit on the chemical and sensory profiles of Barossa 'Shiraz' grapes and wines. Australian Journal of Grape and Wine Research 21:240-53.

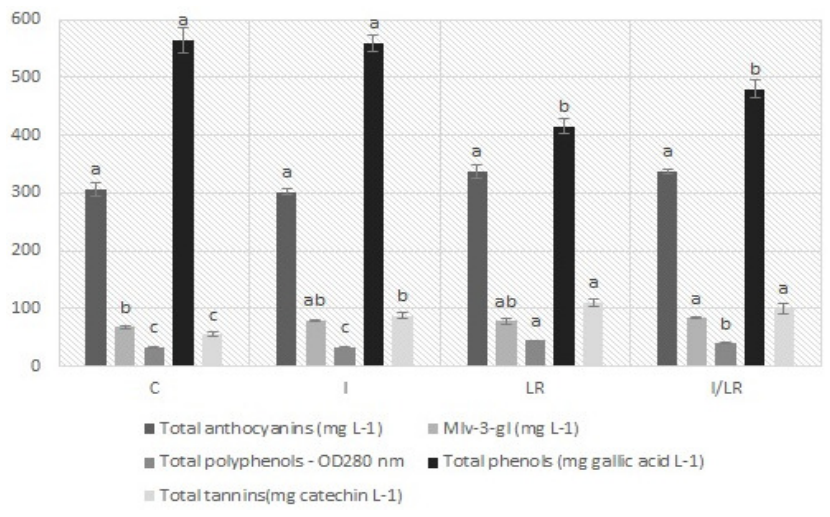

Fig. 2. Wine components measured at harvest. Different letters within a parameter denote significant differences (Tukey's test, $\mathrm{p} \leq 0.05)$.

Bordelon BP, Skinkis PA, Howard PH (2008). Impact of training system on vine performance and fruit composition of 'Traminette'. American Journal of Enology and Viticulture 59:39-46.

Brand-Williams W, Cuvelier ME, Berset E (1994). Use of a free radical method to evaluate antioxidant activity. Lebensmittel-Wissenschaft Technology 28:25-30

Casassa LF, Keller M, Harbertson JF (2015). Regulated deficit irrigation alters anthocyanins, tannins and sensory properties of 'Cabernet Sauvignon' grapes and wines. Molecules 20:7820-7844.

Chorti E, Guidoni S, Ferrandino A, Novello V (2010). Effects of different sunlight exposure levels on ripening and anthocyanin accumulation in 'Nebbiolo' grapes. American Journal of Enology and Viticulture 61:2330.

Dokoozlian NK, Kliewer WM (1996). Influence of light on grape berry growth and composition varies during fruit development. Journal of the American Society for Horticultural Science 121:869-874.

Emmett RW, Harris AR, Taylor RH, McGechan JK(1992). Grape diseases and vineyard protection. Viticulture Vol. 2. Practices. Coombe BG, Dry PR(Eds). Winetitles, Adelaidepp 232-278.

Fereres E, Evans RG (2006). Irrigation of fruit trees and vines: an introduction. Irrigation Science 24:55-57.

Gubler WD, Bettiga LJ, Heil D (1991). Comparisons o hand and machine leaf removal for the control of Botrytis cluster rot. American Journal of Enology and Viticulture 42:233-236.

Harbertson JF, Picciotto EA, Adams DO (2003) Measurement of polymeric pigments in grape berry extracts and wines using a protein precipitation assay combined with bisulfate bleaching. American Journal of Enology and Viticulture 54:301-306. 
138

Haselgrove L, Botting D, Van Heeswijck R, Hoj PB, Dry PR, Ford C, Iland PG (2000). Canopy microclimate and berry composition: the effect of bunch exposure on the phenolic composition of Vitis vinifera $\mathrm{L} \mathrm{cv}$. 'Shiraz' grape berries. Australian Journal of Grape and Wine Research 6:141-149.

Iland P, Bruer N, Edwards G, Weeks S, Wilkes E (2004), Chemical analysis of grapes and wine: techniques and concepts. P. Iland Wine Promotions PTYLTD, Campbelltown, Australia.

Intrieri C, Filippetti I, Allegro G, Centinari M, Poni S (2008). Early defoliation (hand vs mechanical) for improved crop control and grape composition in 'Sangiovese' (Vitis vinifera L.). Australian Journal of Grape and Wine Research 14:25-32.

Jeong ST, Goto-Yamamoto N, Kobayashi S, Esaka M (2004). Effects of plant hormones and shading on the accumulation of anthocyanins and the expression of anthocyanin biosynthetic genes in grape skins. Plant Science 167:247-252.

Kallithraka S, Tsoutsouras E, Tzourou E, Lanaridis P (2006). Principal Phenolic Compounds in Greek Red Wines. Food Chemistry 99:784 793.

Kennedy JA, Matthews MA, Waterhouse AL (2002). Effects of maturity and vine water status on grape skin and wine flavonoids. American Journal of Enology and Viticulture 53:268-274.

Kliewer WM, Lider LA (1968). Influence of cluster exposure to the sun on the composition of 'Thompson Seedless' fruit. American Journal of Enology and Viticulture 19:175-184.

Kotseridis Y, Georgiadou A, Tikos P, Kallithraka S, Koundouras S (2012). Effects of severity of post-flowering leaf removal on berry growth and composition of three red Vitis vinifera L. cultivars grown under semiarid conditions. Journal of Agricultural and Food Chemistry 60:6000-6010.

Koundouras S, Marinos V, Gkoulioti A, Kotseridis Y, Van Leeuwen C (2006). Influence of vineyard location and vine water status on fruit maturation of non irrigated cv. 'Agiorgitiko' (Vitis vinifera L.). Effects on wine phenolic and aroma components. Journal of Agricultural and Food Chemistry 54:5077-5086.

Koundouras S, Hatzidimitriou E, Karamolegkou M, Dimopoulou E, Kallithraka S, Tsialtas JT, Zioziou E, Nikolaou N, Kotseridis Y (2009). Irrigation and rootstock effects on the phenolic concentration and aroma potential of Vitis vinifera L. cv. 'Cabernet Sauvignon' grapes. Journal of Agricultural and Food Chemistry 57:7805-7813.

Kyraleou M, Koundouras S, Kallithraka S, Theodorou N, Proxenia N, Kotseridis $Y$ (2016a). Effect of irrigation regime on anthocyanin content and antioxidant activity of Vitis vinifera L. cv. 'Syrah' grapes under semiarid conditions. Journal of the Science of Food and Agriculture, 96:988-996.

Kyraleou M, Kotseridis Y, Koundouras S, Chira K, Teissedrec PL, Kallithraka S (2016b). Effect of irrigation regime on perceived astringency and proanthocyanidin composition of skins and seeds of Vitis vinifera L. cv. 'Syrah' grapes under semiarid conditions. Food Chemistry 203:293-300.

Lorrain B, Chira K, Teissedre PL (2011). Phenolic composition of 'Merlot' and 'Cabernet-Sauvignon' grapes from Bordeaux vineyard for the 2009vintage: comparison to 2006, 2007 and 2008 vintages. Food Chemistry 126:1991-1999.
Matthews MA, Anderson MM (1989). Reproductive development in Vitis vinifera L.: responses to seasonal water deficits. American Journal of Enology and Viticulture 40:52-60.

Matus JT, Loyola R, Vega A, Peña-Neira A, Bordeu E, Arce-Johnson P, Alcade AJ (2009). Post-veraison sunlight exposure induces MYBmediated transcriptional regulation of anthocyanin and flavonol synthesis in berry skins of Vitis vinifera. Journal of Experimental Botany 60:853-867.

Mori K, Sugaya S, Gemma H (2005). Decreased anthocyanin biosynthesis in grape berries grown under elevated night temperature condition. Scientia Horticulturae 105:319-330.

Ojeda H, Deloire A, Carbonneau A (2001). Influence of water deficits on grape berry growth. Vitis 40:141-145.

Ojeda H, Andary C, Kraeva E, Carbonneau A, Deloire A (2002). Influence of pre- and postveraison water deficit on synthesis and concentration of skin phenolic compounds during berry growth of Vitis vinifera $\mathrm{L} c \mathrm{c}$. 'Shiraz'. American Journal of Enology and Viticulture 53:261-267.

Palliotti A, Gatti M, Poni S (2001). Early leaf removal to improve vineyard efficiency: gas exchange, source-to-sink balance, and reserve storage responses. American Journal of Enology and Viticulture 62:219-228

Percival DC, Fisher KH, Sullivan JA (1994). Use of fruit zone leaf removal with Vitis vinifera $\mathrm{L}$ cv 'Riesling' grapevines. II. Effect on fruit composition, yield, and occurrence of bunch rot. American Journal of Enology and Viticulture 45:133-139.

Ribéreau-Gayon P, Glories Y, Maujean A, Dubourdieu D (1999). Handbook ofEnology, vol. 2.John Wiley \& Sons Ltd, Chichester.

Petrie PR, Trought MCT, Howell GS, Buchan GD (2003). The effect of leaf removal and canopy height on whole-vine gas exchange and fruit development of Vitis vinifera L. cv. 'Sauvignon blanc'. Functional Plant Biology 30:711-717.

Petropoulos S, Kallithraka S, Paraskevopoulos I (2011). Influence of some viticultural practices on the polyphenolic content of wines produced from cv. 'Agiorgitiko' (Vitis Vinifera L.). Journal International des Sciencedela Vigneet du Vin 45:235-243.

Price SF, Breen PJ, Valladao M, Watson BT (1995). Cluster sun exposure and querquetin in grapes and wine. American Journal of Enology and Viticulture 46:187-194.

Reynolds AG, Pool RM, Mattick LR (1986). Influence of cluster exposure on fruit composition and wine quality of 'Seyval blanc' grapes. Vitis 25:85-95.

Ristic R, Downey M, Iland P, Bindon K, Francis L, Henderich M, Robinson $S$ (2007). Exclusion of sunlight from 'Shiraz' grapes alters wine colour, tannin and sensory properties. Australian Journal of Grape and Wine Research 13:53-65.

Roby G, Matthews M (2004). Relative proportions of seed, skin and flesh, in ripe berries from 'Cabernet Sauvignon' grapevines grown in a vineyard either well irrigated or under water deficit. Australian Journal of Grape and Wine Research 10:74-82.

Roby G, Harbertson JF, Adams DA, Matthews MA, (2004). Berry size and vine water deficits as factors in winegrape composition: anthocyanins and tannins. Australian Journal of Grape and Wine Research 10:100107. 
Romero-Cascales I, Ortega-Regules A, Lopez-Roca JM, FernandezFernandez II, Gomez-Plaza E (2005). Differences in anthocyanin extractability from grapes to wines according to variety. American Journal of Enology and Viticulture 56:212-219.

Santesteban LG, Miranda C, Royo JB (2011). Regulated deficit irrigation effects on growth, yield, grape quality and individual anthocyanin composition in Vitis vinifera L. cv. 'Tempranillo'. Agricultural Water Management 98:1171-1179.

Spayd SE, Tarara JM, Mee DL, Ferguson JC (2002). Separation of sunlight and temperature effects on the composition of Vitis vinifera cv. Merlot berries. American Journal of Enology and Viticulture 53:171-182.

Tarara JM, Lee J, Spayd SE, Scagel CF (2008). Berry temperature and solar radiation alter acylation, proportion, and concentration of anthocyanins in Merlot grapes. American Journal of Enology and Viticulture 59:235247.
TardaguilaJ, Martinez de Toda F, PoniS, Diago MP (2010). Impact of early leaf removal on yield and fruit and wine composition of Vitis vinifera $\mathrm{L}$. 'Graciano' and 'Carignan'. American Journal of Enology and Viticulture 61:372-381.

Waterman PG, Mole S (1994). Analysis of phenolic plant metabolites. Oxford: Blackwell Scientific Publ pp 83-91.

Yamane T, Jeong ST, Goto-Yamamoto N, Koshita Y, Kobayashi S (2006). Effects of temperature on anthocyanin biosynthesis in grape berry skins. American Journal of Enology and Viticulture 57:5459.

Zoecklein PW, Wolf TK, Duncan NW, Judge JM, Cook MK (1992). Effects of fruit zone leaf removal on yield, fruit composition, and fruit rot incidence of'Chardonnay' and 'White Riesling' (Vitisvinifera L.) grapes. American Journal ofEnology and Viticulture 43:139-148. 